\title{
Impact of Spraying Some Chemical Substances on Controlling Sunburn of Balady Mandarin Fruits
}

\author{
Manal A. Zaky , Amal A. El-Baowab and Shaimaa A. Mohamed \\ Citrus Research Department, Horticulture Research Institute, Agricultural Research \\ Centre, Cairo, Egypt.
}

\begin{abstract}
QUNBURN is one of the most important problems that may affect the growth, productivity and quality of Balady mandarin trees.

This study was conducted to determine the effects of two kaolin clay products i.e. Screen Duo ${ }^{\circledR}$ (applied once or twice) and Surround ${ }^{\circledR}(3$ and 6\%) used as anti-sunburn treatment on controlling sunburn of Balady mandarin fruits Citrus reticulata.
\end{abstract}

Data indicated that percentage of injured fruits were decreased by treatments in comparison with control in both seasons of study. The percentage of injured fruits in Surround ${ }^{\circledR} 6$ and 3 $\%$ treatments were 11.66 and $14.02 \%$ in first season and 9.33 and $15.5 \%$ in the second one, respectively, while those treated with Screen Duo ${ }^{\circledR}$ once and twice, possessed 19.6 and 14.9 $\%$ in the first season and 20.5 and $16.3 \%$ in the second one compared with control treatment that gained 31.68 and $32.6 \%$ in the first and second seasons, respectively. Surround ${ }^{\circledR} 6 \%$ treatment caused significant increase in fruits weight and volume. The treatments did not affect fruits juice TSS, acidity and TSS/acidity ratio, except Surround ${ }^{\circledR} 6 \%$ treatment, which caused significant increase in both TSS and acidity and significant decrease in TSS/acidity ratio in comparison with injured fruits. In the present study, the economic gain was estimated in term of assumed percentage of increase per fadan value in comparison with the control, where the estimated percentage of increase ranged between 11.6-20.66 in first season and 12.6-21.33 in the second one.

Keywords: Kaolin clay, Citrus reticulata, Sunburn, Rind anatomy, Economic feasibility.

\section{Introduction}

Most of the newly reclaimed areas are cultivated with fruit trees especially citrus which, is considered as the first fruit crop in Egypt (Salama, 2015). Egypt represents about $15 \%$ of the total citrus production in the Mediterranean Basin and occupies the $3^{\text {rd }}$ rank after Spain and Italy (Youseif et al., 2014). Mandarin (Citrus reticulata Blanco) is one of the most important citrus fruits in Egypt, having significant value in the local market. Mandarins are a diverse group of thinskinned, easy-peeling fruits that includes popular citrus types such as satsumas, clementines and tangerines. Mandarins are becoming increasingly popular with consumers, largely due to the ease with which they can be eaten as compared to other types of citrus that are more difficult to peel (Obenland et al., 2011). A survey conducted by Minessy et al. (1969) on the fruit sunburn problem in four citrus varieties in coastal and desert orchards indicated that the sunburn was greatest in the Balady mandarin. Kaolin-based particle films can reduce insect, heat, and ultraviolet stress in horticultural crops because of their ability to modify the microenvironment of the plant canopy as a result of the reflective nature of the particles (Glenn, 2012).

The present research was undertaken to assess the effectiveness of two kaolin clay sunburn mitigating substances i.e. Surround ${ }^{\circledR}$ and Screen Duo ${ }^{\circledR}$, in addition to the anatomy of healthy and injured peel was carried out as well as the economic feasibility of the treatments.

\section{Material and Methods}

This study was conducted at Dina farm $(\mathrm{km}$ 80 Cairo -Alexandria desert road) in seasons 2013 and 2014 seasons, on Balady mandarin (Citrus 
reticulata Blanco) trees budded on sour orange rootstock. The trees were 4 years old, irrigated daily through drip irrigation system and chosen in completely randomized block design, each treatment was applied into three replicates (three trees/replicate).

Two commercially available Kaolin clay

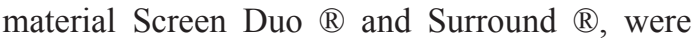
used in the present study for sun burn treatment as reflective foliar coating, the following treatments were carried out:

- $\quad$ control (sprayed with only water)

- Screen Duo ${ }^{\circledR}$ once (1.25 Kg/100 L of water)

- Screen Duo ${ }^{\circledR}$ twice

- Surround ${ }^{\circ} 3 \%$

- $\quad$ Surround ${ }^{\circ} 6 \%$

All treatments were applied at mid-June in both seasons while in case of Screen Duo ${ }^{\circledR}$ applied twice at mid-June and at $1^{\text {st }}$ of July. Each tree received individually $10 \mathrm{~L}$. of the spray solution till runoff.

At harvest time (mid-January) in both seasons, the percentage of injured fruits was recorded. Weight and volume of fruits, peel thickness, TSS and acidity were measured, then TSS acid ratio was calculated.

Collected Data were subjected to analysis of variance and means were compared using LSD test at 5\% level according to Snedecor and Cochran (1980).

\section{Histological study}

Peel samples from the normal and injured areas of mandarin fruits were collected then fixed immediately in F.A.A (10:5:50:35 by volume Formalin: glacial acetic acid: Ethyl alcohol and distilled water). The fixed samples were dehydrated in a graded series of Tertiary butyl alcohol (TBA) and ethyl Alcohol according to Sass, (1951). After dehydration procedures, samples were embedded in pure melted paraffin and after tissues saturation with paraffin wax, they were oriented in paper trays and cooled down. Paraffin blocks were prepared and cut into sections $10 \mu \mathrm{m}$ thick using rotary microtome. Paraffin sections in a ribbon form were fastened to a glass slides with an adhesive solution. After deparaffined, peel sections were stained with hematoxylin dye then enclosed with Canada balsam and covered with glass. Peel sections were then examined and photographed.

\section{Economic feasibility study}

The economic return of the treatment were estimated by calculating the expected yield/tree and the expected enhancement in the fruit quality category due to sun-burn reduction, then the yield value for fadan treated with each treatment after cost subtraction due to treatment (in control treatment the cost $=$ zero). Then the percentages of increase in the price in comparison with control were calculated.

\section{Results}

The effect of sunburn on rind anatomy

Various researchers reported that injured fruits with sunburn usually had dark brown spots on the peel on the side that exposed to the sun, such spots appeared as dark asymmetrical area (Sadamatsu, 1981, Wardowski et al., 1986 and Myhob et al., 1996). Citrus fruit is hesperidium composed of three main sections, namely (from inside) endocarp or pulp, mesocarp or albedo finally the outer part exocarp or flavedo, both mesocarp and exocarp together make the pericarp (the peel or rind) (Ford, 1942, Scott \& Baker, 1947 and Ladanyia, 2008). Flavedo is covered with protective cuticle thin layer, while it consists of epidermal cells which are polygonal and isodiametric in shape with no intercellular spaces and hypodermal parenchymatous cells which is located immediately below the epidermis and surrounding the oil glands. Such glands are spherical to slightly oval in profile, thin walled, highly vacuolated and they increase gradually in size deeper in the rind with small intercellular spaces (Agusti, et al., 2001 and Ladanyia, 2008). Figures (1 and 2) showed cross-section of flavedo of uninjured and injured fruit, respectively. It was clear that healthy fruit showed intact cuticle and flavedo, while in the injured fruit cuticle, epidermis and the outer rows of hypodermis were collapsed and became brown in color.

\section{Percentages of injured fruits}

Figure 3 indicated that the percentage of injured fruits were decreased by applied treatments compared to control in both seasons. It is clear that treated trees with Surround $(\circledR$ at $6 \%$ showed the lowest percentage of injured fruits (11.67\%) followed by Surround ${ }^{R}$ at 3\% (14.02\%), Screen Duo $\AA$ applied twice (14.93\%) Screen Duo $®$ applied once (19.6\%), then control (31.69\%). The same trend held true in the second season, where the percentages of injured fruits were 9.33, 15.5, $16.3,20.5$, and $32.6 \%$, respectively. 


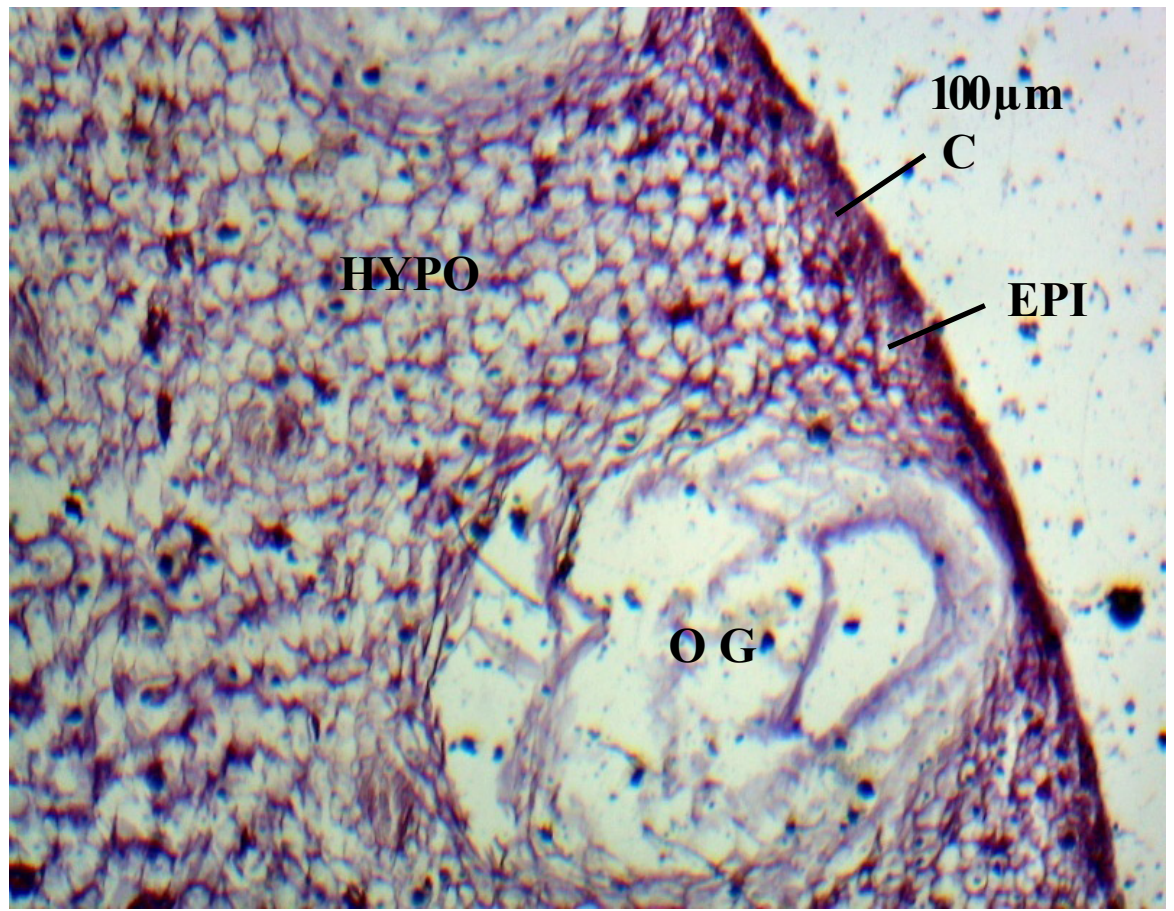

Fig. 1 . Cross-section in the peel of uninjured fruit. C: cuticle EPI: epidermal cells HYPO: hypodermal cells O G: oil glands.

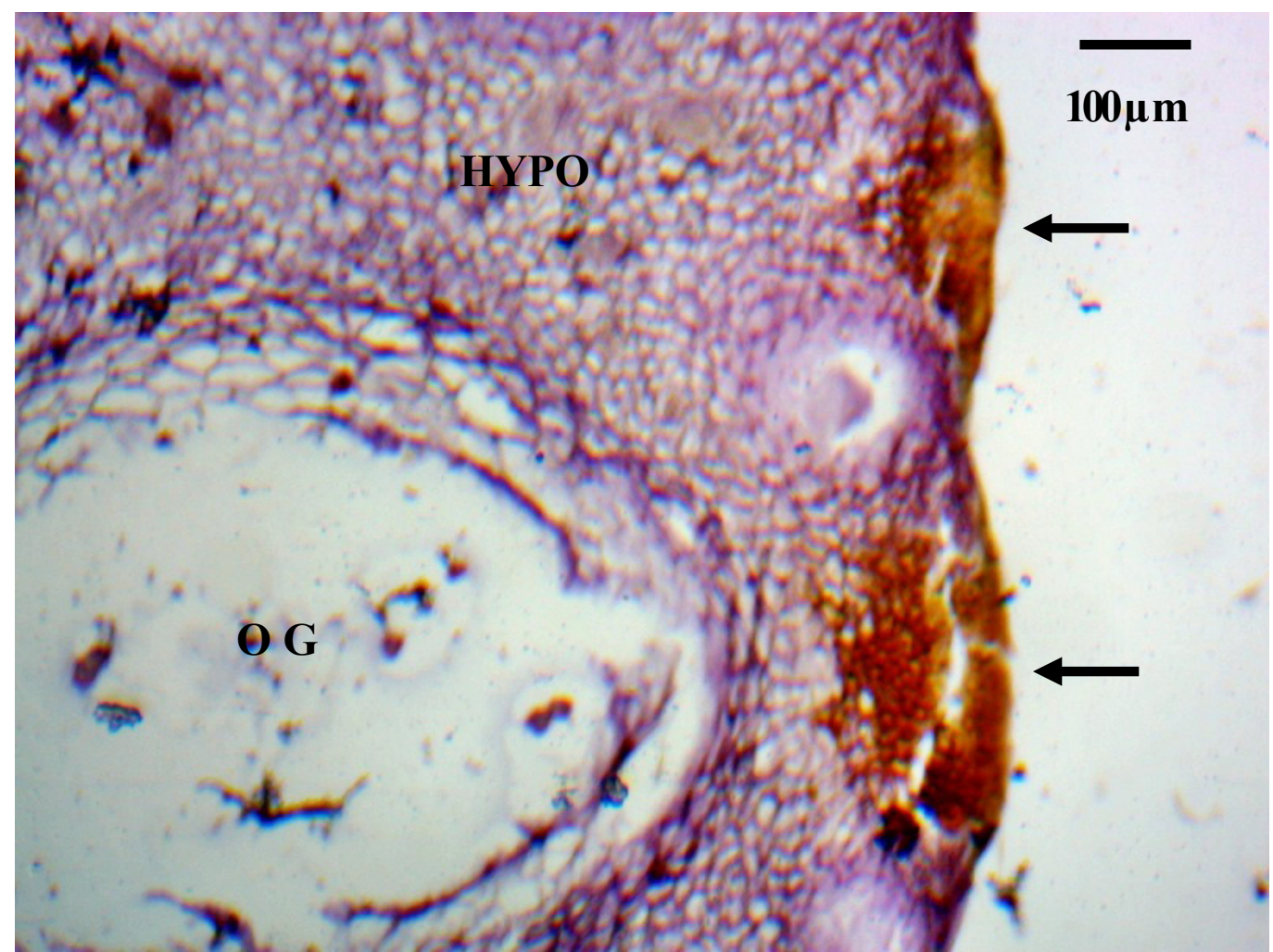

Fig. 2. Cross-section in the peel of injured fruit. Collapsed cuticle and flavedo cells arrowed 


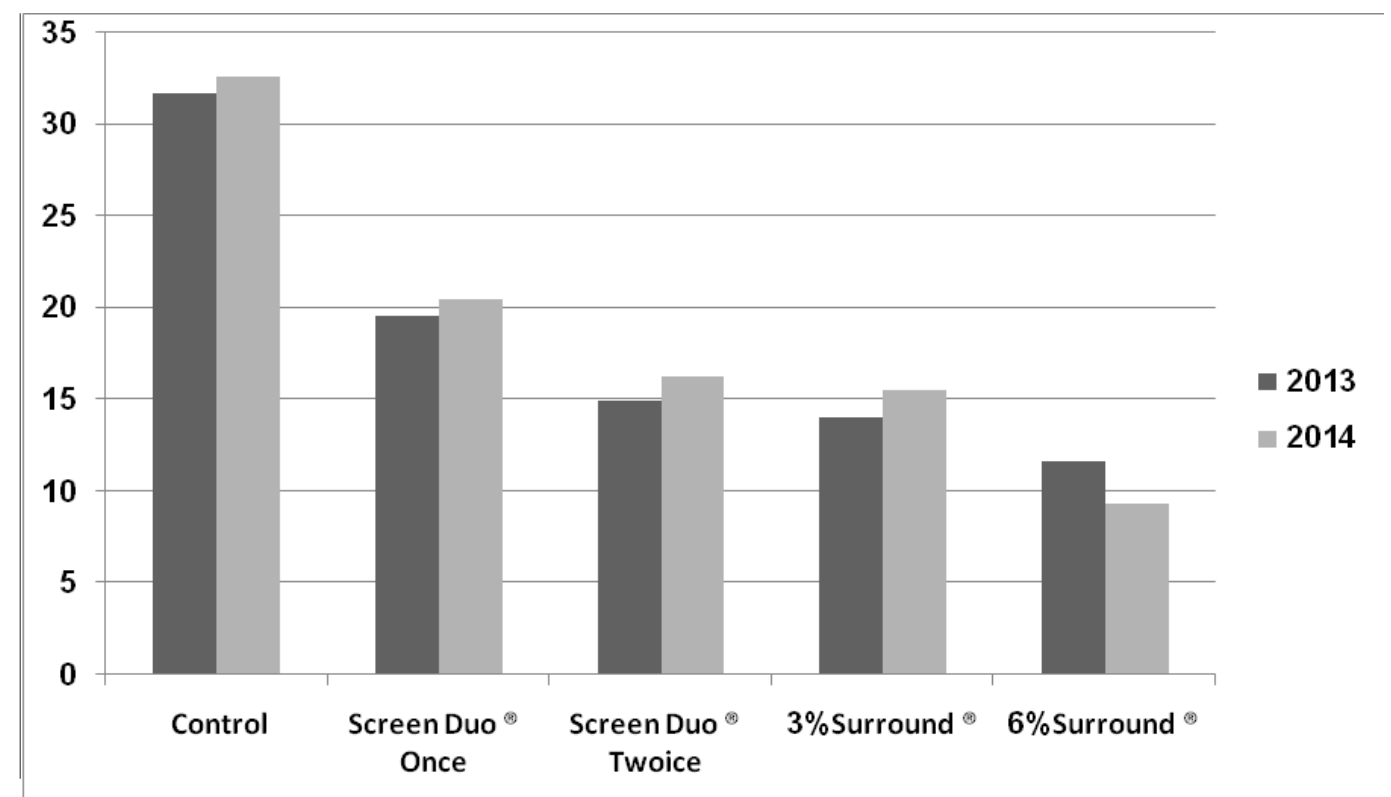

Fig. 3. Effect of Surround ${ }^{\circledR} \quad$ and Screen Duo ${ }^{\circledR} \quad$ on percent of injured fruits of Balady mandarin in 2013 and 2014.

Fruit weight, volume and peel thickness

Data in Table 1 showed the effect of tested materials on the fruit weight, volume and peel thickness from treated trees. Treated trees with Surround ${ }^{\circledR}$ at $6 \%$ had significantly heavier fruits than other treatments, control and injured fruits. The injured fruits weights were significantly lower than other treatments.

As for fruit volume, it was clear that trees treated with Surround $₫$ at $6 \%$ gained significant increase in the fruit volume as compared with other treatments and control, while other treatments were significantly higher than control, but injured fruits showed the lowest fruits volume comparing with control. The average fruits volume of first and second season were 136.48, 145.72, 141.07, 156.31, 129.79 and $102.30 \mathrm{Cm}^{3}$ for Screen Duo ${ }^{\circledR}$ applied once and twice, Surround $\AA$ at $3 \%$ and $6 \%$, control and injured, respectively.

TABLE 1. Effect of Surround ${ }^{\circledR}$ and Screen Duo ${ }^{\circledR}$ on the fruit weight, volume and peel thickness of Balady mandarin in the seasons (2013 and 2014)

\begin{tabular}{|c|c|c|c|}
\hline Treatments & $\begin{array}{c}\text { Fruit weight } \\
\text { (gm.) } \\
\end{array}$ & $\begin{array}{c}\text { Fruit volume } \\
\left(\mathrm{cm}^{3}\right) \\
\end{array}$ & $\begin{array}{l}\text { Peel thickness } \\
\text { (mm) }\end{array}$ \\
\hline & \multicolumn{3}{|c|}{ Season 2013} \\
\hline Control & 126.22 & 134.22 & 2.65 \\
\hline Screen Duo ${ }^{\circledR}$ applied once & 132.00 & 138.44 & 2.73 \\
\hline Screen Duo ${ }^{\circledR}$ applied twice & 137.15 & 147.99 & 2.78 \\
\hline Surround $\AA 3 \%$ & 132.98 & 140.37 & 2.76 \\
\hline Surround ${ }^{\circledR} 6 \%$ & 142.22 & 155.66 & 2.88 \\
\hline Injured & 97.11 & 101.33 & 2.27 \\
\hline \multirow[t]{2}{*}{ L.S.D $(0.5)$} & 4.15 & 7.5 & 0.59 \\
\hline & \multicolumn{3}{|c|}{ Season2014 } \\
\hline Control & 126.89 & 125.36 & 2.56 \\
\hline Screen Duo ${ }^{\circledR}$ applied once & 127.81 & 134.52 & 2.61 \\
\hline Screen Duo ${ }^{\circledR}$ applied twice & 135.61 & 143.45 & 2.88 \\
\hline Surround $\AA 3 \%$ & 131.92 & 141.77 & 2.73 \\
\hline Surround $\AA 6 \%$ & 140.48 & 156.96 & 2.89 \\
\hline Injured & 95.11 & 103.27 & 2.53 \\
\hline L.S.D $(0.5)$ & 4.8 & 7.2 & 0.42 \\
\hline
\end{tabular}

Egypt. J. Hort. Vol. 45, No. 2 (2018) 
In both seasons the treatments did not affect the fruits peel thickness in comparison with the control, but the peel thickness of fruits treated with Surround $($ $6 \%$ was significantly thicker than peel of injured fruits.

Total soluble solids (TSS), acidity and TSS/TA ratio

Data in Table 2 showed that there was no positive impact on TSS by applying the different treatments, but there were significant differences

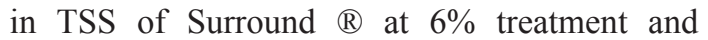
injured fruits. Also Surround $\AA$ at $6 \%$ treatment scored the highest acidity mean, while, injured fruits showed significantly low acidity content. As for TSS/TA ratio, there were no significant differences between treatments but injured fruits showed significantly high ratio.

\section{Economic feasibility of the treatments}

In the present study the economic gain were estimated in term of assumed percentage of increase in fadan value in comparison with the control.

Fig. 4 Showed the economic feasibility of the tested materials. It could be concluded that treatments increased the value of treated trees, where the percentages of increase in 2013 were: 11.6, 13.5, 15.2 and $20.66 \%$ after treatment with Screen Duo ${ }^{\circledR}$ applied once and twice and Surround $\AA$ at $3 \%$ and $6 \%$, respectively. While it were in 2014: 12.6, 15.4, 16.5 and $21.33 \%$, respectively.

TABLE 2. Effect of Screen Duo ${ }^{\circledR}$ and Surround ${ }^{\circledR}$ on the fruits juice total soluble solids (TSS), acidity and TSS/ TA ratioof Balady mandarin in the seasons (2013 and 2014)

\begin{tabular}{|c|c|c|c|}
\hline Treatments & Soluble solids TSS (\%) & Acidity & TSS/TA ratio \\
\hline & \multicolumn{3}{|c|}{ Season 2013} \\
\hline Control & 10.10 & 1.26 & 8.08 \\
\hline Screen Duo ${ }^{\circledR}$ applied once & 10.08 & 1.29 & 7.85 \\
\hline Screen Duo ${ }^{\circledR}$ applied twice & 10.15 & 1.41 & 7.24 \\
\hline Surround $® 3 \%$ & 10.10 & 1.41 & 7.18 \\
\hline Surround $® 6 \%$ & 10.18 & 1.31 & 7.18 \\
\hline Injured & 10.00 & 1.09 & 9.24 \\
\hline \multirow[t]{2}{*}{ L.S.D $(0.5)$} & 0.19 & 0.15 & 1.8 \\
\hline & \multicolumn{3}{|c|}{ Season 2014} \\
\hline Control & 10.13 & 1.30 & 7.84 \\
\hline Screen Duo ${ }^{\circledR}$ applied once & 10.06 & 1.30 & 7.74 \\
\hline Screen Duo ${ }^{\circledR}$ applied twice & 10.15 & 1.42 & 7.17 \\
\hline Surround $® 3 \%$ & 10.30 & 1.42 & 7.29 \\
\hline Surround $® 6 \%$ & 10.15 & 1.37 & 7.45 \\
\hline Injured & 10.12 & 1.08 & 9.36 \\
\hline L.S.D $(0.5)$ & 0.25 & 0.20 & 1.9 \\
\hline
\end{tabular}

\section{Discussion}

The present study showed that the percentage of injured fruits decreased in comparison to control, "Surround $\AA$ " at $6 \%$ treatment showed the lowest percent of injured fruit (11.66 and $9.33 \%$ in both seasons), Kaolin particles film was also successful in sunburn reduction in Ruby Red grape fruit leaves (Jifon and Syvertsen, 2003), and Anna Apple (Aly et al., 2010).
The major causes of sunburn on citrus crop are high temperature and high intensity of solar radiation (Ketchie, 1969, Myhob et al., 1996, Jifon \& Syvertsen, 2003 and Tsai et al., 2013). In the present study the treatments caused reduction in sunburned fruits may be due to their reflective nature of the solar radiation. Tsai et al. (2013) reported that shading treatment resulted in $0 \%$ sunburn in Murcott tangor fruit. 


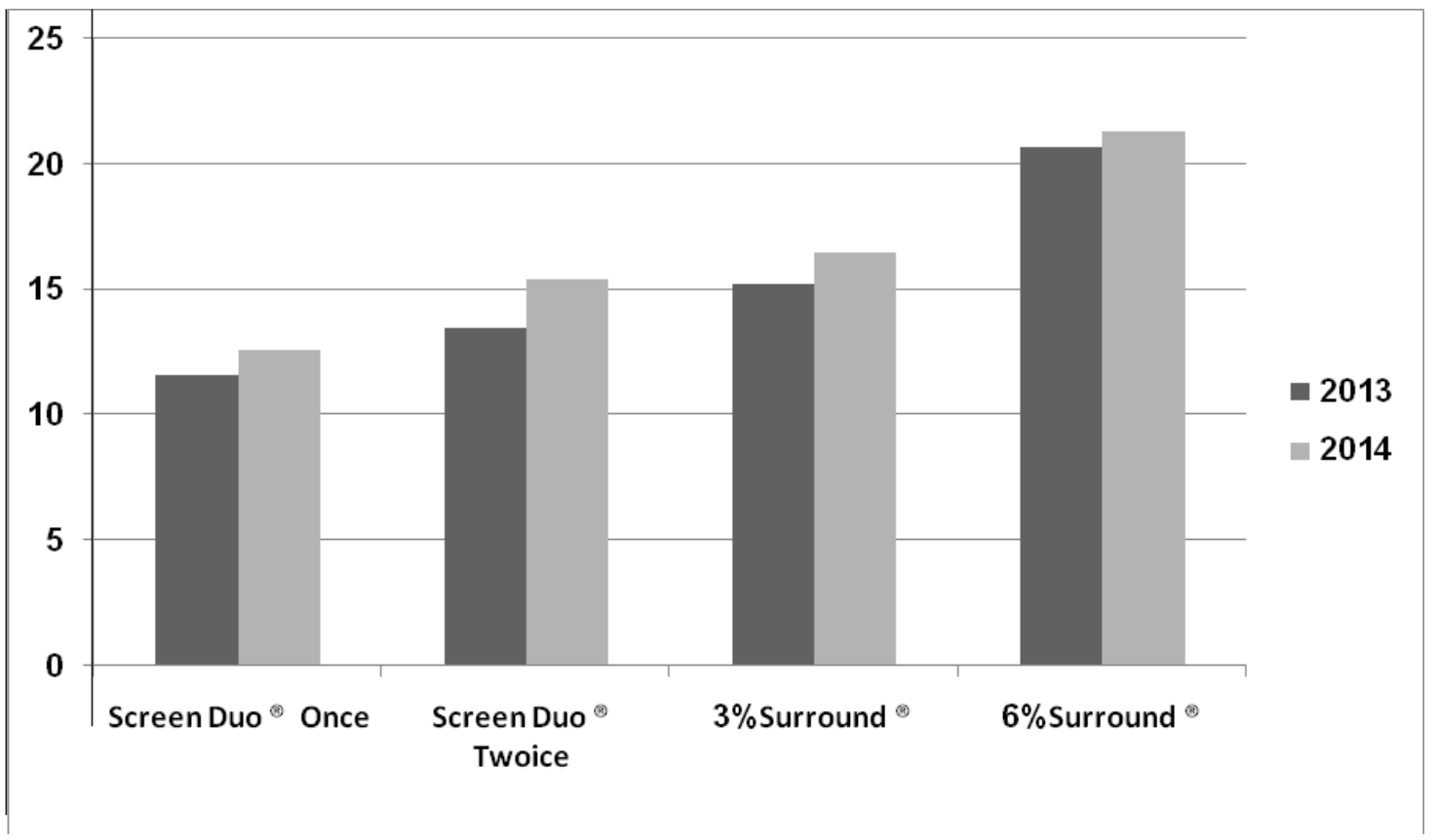

Fig. 4. Effect of Surround ${ }^{\circledR}$ and Screen Duo ${ }^{\circledR} \quad$ on economic feasibility of the treatments in 2013 and 2014

All treatments caused significant increase in fruits weight and volume when compared to control, but injured fruits significantly decreased than control, this finding is in line with those results of Myhob et al. (1996), Jifon and Syvertsen, (2003) and Tsai et al. (2013). Also Ketchie and Ballard (1968) reported that fruit grown under full exposure to the sun were smaller and weighted less than fruits grown in the shade. Such increase in fruits weight and volume may be due to increase of photosynthesis rates. Jifon and Syvertsen, (2003) reported that grapefruit leaves treated with kaoline film particles caused an increase in stomatal gas exchange of leaves, $\mathrm{Co}_{2}$ assimilation rates and water use efficiency. The sunburn treatments in the present study did not affect the fruit juice quality (TSS and acidity) in comparison with control. This finding agree with Tsai et al. (2013) results. While total soluble solids and acidity of injured fruits decreased significantly in contrary with Myhob et al. (1996) results.

In the present study healthy fruit showed intact cuticle and flavedo, while in the injured fruit cuticle, epidermis and the outer rows of hypodermis were collapsed and became brown in color. Extreme loss of water may be the main reason for cuticle and flavedo cells breakdown. Kaolin film caused reduction of heat due to it is reflective nature (Glenn, 2012).

Egypt. J. Hort. Vol. 45, No. 2 (2018)
It was expected that the treatment increased the value of the treated fruits by enhancing the fruit quality category and covered the cost of treatments.

Thus, it could be concluded that applying Surround ${ }^{\circledR} 6 \%$ in mid-June resulted in the lowest percentage of sunburn to mandarin fruits.

\section{Acknowledgment}

The authors would like to express their deep thanks to the central laboratory of Horticulture Research Institute for their help in all chemical analysis of the current study.

\section{Funding statements}

The studies reported in this publication, were partially supported by Horticulture Research Institute, Agriculture Research Center.

\section{Conflicts of interest}

The authors certify that they have NO affiliations with or involvement in any organization or entity with any financial interest or non-financial interest in the subject matter or materials discussed in this manuscript.

\section{References}

Agustí, M., Almela, V., Juan, M., Alferez, F., Tadeo, F.R. and Zacarías, L. (2001) Histological and physiological characterization of rind breakdown of 'Navelate' sweet orange. Annals of Botany, 88, 415-422. 
Aly, M., Abd El-Megeed, N. and Awad, R.M. (2010) Reflective particle films affected on, sunburn, yield, mineral composition and fruit maturity of Anna apple (Malus domestica) trees . Res. J. Agric.\& Biol. Sci., 6 (1), 84-92.

Ford, E.S. (1942) The anatomy and histology of the Eureka Lemon. Bot. Gaz. 104, 288-305.

Glenn, D.M. (2012) The mechanisms of plant stress mitigation by kaolin based particle films and applications in horticulture and agricultural crops. Hort. Science, 47 (6), 710-711.

Jifon, J.L. and Syvertsen, J.P. (2003) Kaolin particle film application can increase Photosynthesis and water use efficiency of Ruby Red Grapefruit leaves. J. Amer. Soc. Hort. Sci., 128, 107-112.

Ketchie, D.O. (1969) The effect of high temperature on citrus. Proceedings $1^{\text {st }}$ International Citrus Symposium, 1, 267-270.

Ketchie, D.O. and Ballard A.L. (1968) Environments which cause heat injury to valencia oranges. Proceedings of the American Society for Horticultural Science, 93, 166-172.

Ladanyia, M. (2008) Citrus Fruit: Biology, Technology and Evaluation. USA: Elsevier publications, pp. $103-124$.

Minessy, F.A., Nasr, T.A.A. and El-Shurafa M.Y. (1969) Citrus fruit temperature in relation to sunburn. Proceeding of the Conference on tropical and subtropical fruits. Londen School of pharmacy, Brunswick Square, 245-252.

Myhob, M.A., Guindy, L.F. and Salem, S.E. (1996) Influence of sunburn on Balady mandarin fruits and its control. Bull. Fac. Agric. Univ. Cairo, 47, 457470 .

Obenland, D., Collin, S., Mackey, B., Sievert, J. and Arpaia, M. (2011) Storage temperature and time influences sensory quality of mandarins by altering soluble solids, acidity and aroma volatile composition. Postharvest Biology and Technology, 59, 187-193.

Sadamatsu, M. (1981) Occurrence of sunscald in early Satsuma mandarin and its control. Proc Int. Soc. Citriculture, 1, 205-207.

Salama A, S.M. (2015) Effect of Algae Extract and Zinc Sulfate Foliar Spray on Production and Fruit Quality of Orange Tree cv. Valencia. Journal of Agriculture and Veterinary Science, 8 (9), 51-62.
Sass, J. E. (1951) Botanical Microtechnique. $2^{\text {nd }}$ ed., The Iowa State College Press, Ames, Iowa, U.S.A.

Scott, F.M., and Baker, K.C. (1947) Anatomy of 'Washington' navel orange rind in relation to water spot. Bot. Gaz., 108, 459-475.

Snedecor, G.W. and Cochron, W.G. (1980) "Statistical Methods", $7^{\text {th }}$ ed. Iowa State University Press, Ames, 507 p.

Tsai, M.S., Lee, T.C., and Chang, P.T. (2013) Comparison of paper bags, calcium carbonate, and shade nets for sunscald protection in 'Murcott' tangor fruit. Hort. Technology, 23 (5), 659-667

Wardowski W.F., Nagy, S. and Grierson, W. (1986) Fresh Citrus Fruits, Van Nostrand Reinhold Co. U.S.A., 364 p.

Youseif, S. H., El- Halwagi, A., Sayed, H. A. and ElItriby, Hanaiya A. (2014) Chemical analyses, antibacterial activity and genetic diversity assessment of some Egyptian Citrus spp. Cultivars. African Journal of Biotechnology, 13 (26), 26262636.

(Received 22/04/2018; accepted 03/07/2018) 


\section{تأثير الرش ببعض المواد الكيميائية على التحم فى لفحة الثمس فى ثمار اليوسفى البلاى \\ منال عباس زكى و امل احمد البواب و شيماء عبدالمنعم محمد

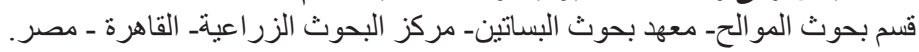

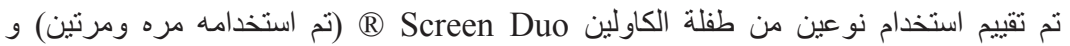
( Surround

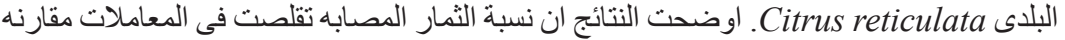

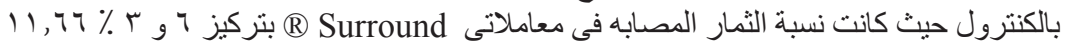

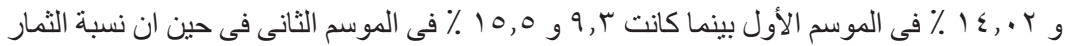

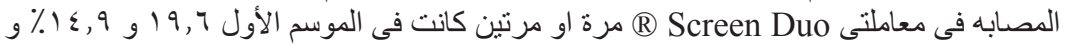

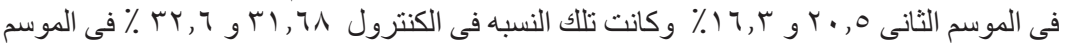

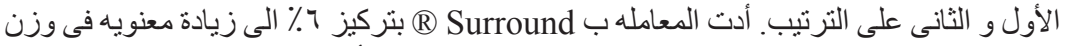

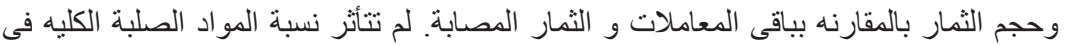

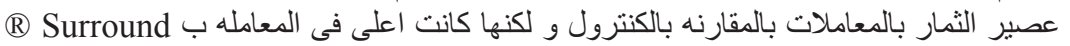

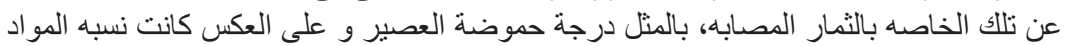

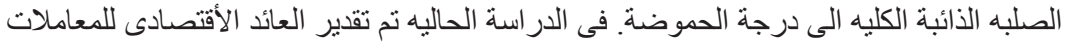

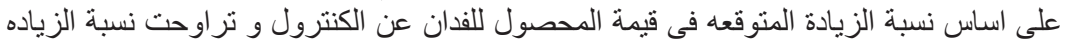

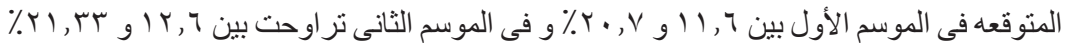

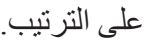

